\title{
Türkçe deyimler kitapçı̆̆ı: Spécimen des Idiotismes de la Languae Turque - Recueillis, classés par ordre de matières et expliqués
}

Yakup YILMAZ

Ceylan AKSOY²

\begin{abstract}
APA: Yılmaz, Y.; Aksoy, C. (2019). Türkçe deyimler kitapçı̆̆ı: Spécimen des Idiotismes de la Languae Turque - Recueillis, classés par ordre de matières et expliqués. RumeliDE Dil ve Edebiyat Araşturmaları Dergisi, (Ö6), 65-78. DOI: 10.29000/rumelide.648421.
\end{abstract}

$\ddot{\mathbf{O} z}$

Genellikle gerçek anlamından az çok ayrı, kendine özgü bir anlam taşıyan kalıplaşmış söz öbeği, tabir diye tanımlanan deyimler, her dilin sanatlı söz varlıklarındandır. Köktürkçeden günümüze kullanılan deyimler, yabancı Türkologların da ilgilendiği konulardan olmuştur. Fransa Asya Araştırmaları Cemiyeti üyesi olan F. L. O Roehrig tarafından kaleme alınan ve Türkçe öğretiminde kullanılması amaçlanan Spécimen des Idiotismes de la Languae Turque - Recueillis, classés par ordre de matières et expliqués adlı eserde de deyimler derlenmiştir. Türkçeye Türk Dilinin Deyimleri diye çevrilebilen eser, deyimleri ihtiva ediyormuş gibi görünse de deyimlerin yanında deyim dışı söz varlığı unsurlarını da barındırmaktadır. 8 Ekim 1843 tarihinde Breslav'da tamamlanan eserde, madde başları tematik olarak tasnif edilmiş, temaların altında alfabetik olarak deyimler sıralanmıştır. Sol sütunda Osmanlı Türkçesi, karşısında da Fransızcası yer almaktadır. Yaygınlaşıp kalıplaşmış benzetmeleri de deyim sayan Roehrig, bu eseriyle devrin Türkçe söz varlığını kayda geçirmekle faydalı bir çalışma bırakmıştır. 38 sayfadan ibaret olan Spécimen des Idiotismes de la Languae Turque - Recueillis, classés par ordre de matières et expliqués adlı eser bu çalışmada etraflıca değerlendirilecek, deyim çalışmalarına bir kaynak sunulacaktır.

Anahtar kelimeler: İdyotizm, deyim, transkripsiyon metni, söz varlığı.

\section{Idioms book of Turkish: Spécimen des Idiotismes de la Languae Turque - Recueillis, classés par ordre de matières et expliqués}

\begin{abstract}
Phrases, often referred to as stereotyped phrases, which are more or less distinct from their true meaning, are one of the artistic vocabulary of each language. The idioms of Turkish have been manifest since the past. The idioms used from Köktürk Turkish to the present day have been among the subjects that foreign Turkologists are interested in. Expressions were also compiled in the book Spécimen des Idiotismes de la Languae Turque - Recueillis, classés par ordre de matières et expliqués, written by F. L. O Roehrig, a member of the Society for Asian Studies in France, intended to be used in teaching Turkish. Although it may seem to contain idioms, the work, which can be translated into Turkish as Idioms of the Turkish Language, also contains elements of non-idiom vocabulary besides idioms. Completed in Breslav on 8 October 1843, the work classified thematic headings and listed the idioms in alphabetical order under the themes. In the left column is Ottoman yilmazyakupbey@gmail.com, ORCID ID: oooo-0001-6230-8850 [Makale kayit tarihi: 10.10.2019-kabul tarihi: 20.11.2019; DOI: 10.29000/rumelide.648421]

2 YL Öğrencisi, Kırklareli Üniversitesi, Sosyal Bilimler Enstitüsü, Türk Dili ve Edebiyatı ABD (Kırklareli, Türkiye), cylnaksy@gmail.com, ORCID ID: 0000-0002-3111-8904.
\end{abstract}




\begin{abstract}
Turkish and in the opposite French. Roehrig, who considers the common and stereotyped parables as idioms, has left a useful study in recording the Turkish vocabulary of the period with this work. Spécimen des Idiotismes de la Languae Turque - Recueillis, classés par ordre de matières et expliqués, which consists of 38 pages, will be thoroughly evaluated in this paper and a resource will be presented for idiom studies.
\end{abstract}

Keywords: Idiotism, idiom, transcription text, vocabulary.

\title{
1. Giriş
}

\subsection{Deyim nedir?}

Söz varlığı kapsamında temel söz varlığı, terimler, deyimler, atasözleri, ilişki sözleri, veciz sözler ve doldurma sözler yer alır. Anlam değişmeleri sürecinde çeşitli kullanımlar zaman içinde terim olabilir, ilişki söz özelliği kazanabilir, atasözü olarak kalıplaşabilir, çeşitli derecelerde aktarma veya benzetmelerle deyimler de oluşabilir.

Deyim, ifade gücünü artırmak için bir araya getirilen ve genellikle gerçek anlamları dışında bir anlam kazanarak kalıplaşan kelime öbeği, tâbir, 1stılâh (Ayverdi, 2011, s. 279b); gerçek anlamından farklı bir anlam taşıyan ve çekici bir anlatım özelliğine sahip olan kelime öbeği (Korkmaz Z. , Gramer Terimleri Sözlüğü, 1992, s. 43); çekici bir anlatım özelliği taşıyan, genellikle gerçek anlamından ayrı bir anlamı bulunan kalıplaşmış kelime öbeği olarak tanımlanır.

\subsection{Deyimlerin tasnifi}

Deyimler çeşitli şekillerde tasnif edilmiştir. Söz dizimsel özelliklerine göre deyimleri Demir şöyle tasnif etmiştir (2008, s. 431-442):

1. Bir fiil veya fiilimsi üzerinde oluşan deyimler: 1.1. Birleşik fiil yapısında olan deyimler: kulak misafiri ol-; 1.2. Bir fiilimsi üzerinde oluşan deyimler: 1.2.1. İsim fiil üzerinde oluşanlar: tepeden inme (kararlar); 1.2.2. Sifat fiil üzerinde oluşanlar: yere bakan yürek yakan; 1.2.3. Zarf fiil üzerinde oluşanlar: bahk kavağa çıkınca; 1.3. Cümle yapısında olan deyimler: Ateş olsan düştüğün yeri yakarsın: 1.3.1. Basit cümle yapısında olanlar: Başımdan kaynar sular döküldü.; 1.3.2. Şartlı birleşik cümle yapısında olanlar: Hangi taşı kaldırsan altından o çıkar.; 1.3.3. Sıralı cümle yapısında olanlar: Boşa koydum dolmadl, doluya koydum almadı.; 1.3.4. Bağlı cümle yapısında olanlar: Sakalım yok ki sözüm dinlensin.; 1.3.5. Soru cümlesi yapısında olanlar: Hangi dağda kurt öldü?; 1.3.6. Eksiltili cümle yapısında olanlar: Darısı başına...; 1.3.7. Diyalog biçiminde olanlar: -Akıllınız kim? -En öndeki zincirli!

2. Fiilsiz oluşan deyimler: 2.1. İsim tamlaması yapısında olanlar: kafa dengi, ömür törpüsü; 2.2. Sifat tamlaması yapısında olanlar: aslan yürekli, cin fikirli; 2.3. Edat grubu yapısında olanlar: ele güne karşı, yerden göğe kadar; 2.4. Bağlama grubu yapısında olanlar: ha Ali Hoca ha Hoca Ali; 2.5. İsnat grubu yapısında olanlar: eli kulağında, kulağı delik; 2.6. Yönelme grubu yapısında olanlar: başa bela, bire uzun ikiye kısa; 2.7. Bulunma grubu yapısında olanlar: yükte hafif pahada ağır, denizde damla; 2.8. Ayrılma grubu yapısında olanlar: kıldan ince kıllçtan keskin, başından aşkın; 2.9. İkileme (tekrar grubu) yapisinda olanlar: kim kime dum duma.

3. Tek sözcükten ibaret deyimler: dünyalık, gözde. 


\subsection{Deyimlerin özellikleri}

Deyimler, yapılarındaki ortak bazı özelliklerden dolayı diğer söz varlığı unsurlarıyla karıştırılabilmekte, bunun ayrımı da kolay olamamaktadır. Yüceol Özezen’in belirlemesine göre deyim-atasözü, deyimbirleşik fiil, deyim-kalıp söz, deyim-argo kargaşası yaşanmaktadır (2001, s. 874-877).

$\mathrm{Bu}$ kargaşaya rağmen deyimleri diğer söz varlığı unsurlarından ayıran özellikleri Aksoy şöyle belirlemiştir (Aksoy, 1994, s. 498-508):

1. Deyimlerin en önemli bölüğ̈̈; kavramları, değişmece yoluyla anlatım güzelliği ve özgünlüğü içinde belirten kalıplaşmış sözcük öbekleri ya da tümcelerdir: abayı yakmak.

2. Kimi deyimlerin yan özelliği, iki yarglı ve uyaklı olmasıdır: yere bakan yürek yakan.

3. Kimi deyimlerin yan özelliği, öykücük ya da konuşma biçiminde olmasıdır: Akıllınız kim? -En öndeki zincirli.

4. Kimi deyimlerin yan özelliği, bir öyküye ya da bir olaya dayanmasıdır: Ahfeş̧in keçisi gibi başııı sallamak.

5. Kimi deyimlerin yan özelliği, âdetleri, inanışları, gelenekleri bildirmesidir: Tuz ekmek hakkl.

6. Kimi deyimler bir kavramı belirtmek için kurulan, kalıplaşmış söz topluluğudur: Âdet yerini bulsun diye.

7. Kimi deyimlerin özelliği, belli dilbilgisi kurallarıla değil, özel biçimlerle kurulmuş olmasıdır: aklı sira, uzun uzadiya.

8. Kimi deyimler eksiltili anlatım biçimidir: göz göze, diş dişe.

9. Deyimlerin bir türü de ikilemedir ancak bir sözcüğ̈̈n yinelenmesi deyim sayllmaz: yalan dolan, yorgun argin.

10. Kimi deyimler, bir sözcüğün özel bir yardımcı eylemlikle kurulmasından oluşmuştur: abayı yakmak.

Ayrıca deyimler, bir dilin anlatım yollarını, o dili konuşan toplumun geçmişini, yaşam biçimini, geleneklerini ve çeşitli özelliklerini belirten önemli ipuçları sağlarlar (Aksan, 1995, s. 360).

\section{Deyim sözlükleri}

Deyimler çoklukla atasözleriyle birlikte anıldıkları için sözlükleri de atasözleri ve deyimler sözlüğü başlı̆̆ıyla verilmiştir. Eminoğlu'nun atasözü ve deyimlerle ilgili olarak verdiği sözlük tasnifi şöyledir (2010, s. 172-185): 1. Yazma atasözü ve deyim sözlükleri (10 adet), 2. matbu atasözü ve deyim sözlükleri (163 adet), 3. konularına göre ayrımlanmış atasözü ve deyim sözlükleri (13 adet), 4. metinlerden seçilmiş atasözü ve deyim sözlükleri (2 adet), 5. lehçe ve ağılardaki atasözü ve deyimlerin sözlükleri (22 adet), 6. iki ya da çok dilli atasözü ve deyim sözlükleri (26 adet).

Roehrig’in Des Idiotismes de la Langue Turque adlı deyimler sözlüğü de konularına göre ayrımlanmış sözlüklerden sayllır.

\section{Roehrig’in Des Idiotismes de la Langue Turque adlı deyim sözlüğü}

\subsection{Eserin düzeni}

Spécimen des Idiotismes de la Languae Turque - Recueillis, classés par ordre de matières et expliqués (Türkçenin Örnekli Deyimleri- Toplu, Maddeleri sıralı ve tasnifli, Açıklamah) 
adlı eser, Société Asiatique de France üyesi bilim insanı olan F.L.O. Roehrig tarafından kaleme alınmış, Breslav'da 8 Ekim 1843’te basılmış, Londra'da, Paris’te Petersburg’ta da satışı yapılmıştır.

Eserin düzeni şöyledir:

Dış kapak: Dış kapak kartondur. Spécimen des Idiotismes de la Languae Turque - Recueillis, classés par ordre de matières et expliqués biçiminde eser adı; altında F. L. O. Roehrig olarak müellif adı ve müellifin üye olduğu yer olan Société Asiatique de France derneğinin adı; altında al-macāzu kantara ${ }^{t u}$ 'l-ḥaḳiḳat sözü; altında desen ve desen altında yayın yeri olan Breslav ve hemen altında eserin satıldığı yerler olan Londra, Paris ve Petersburg adları geçer. Son satırda da eserin basım tarihi, 1843 yer alır.

İç kapak: İç kapak dış kapaktan farklı bir ifade ve ibare taşımaz. Aynı bilgiler iç kapakta da yer almıştır. İç kapak Romen rakamlarıyla eserin I. sayfasıdır. II. sayfa ise boştur.

Ön söz: III. sayfadan itibaren başlayan Ön söz, VI. sayfada son bulur. Ön söz’de ise şu ifadeler dikkat çeker:

Ön söz’de yazar, Türkçenin sistemli ve dahice kurgulanmış bir gramerinin olduğuna, bir isim ve bir fiilden yeni fiiller, yeni deyimler kurmanın kolaylığına, özellikle Türkçede deyimlerin araştırılmasının zaruretine ve faydasına, deyimlerin incelenmesiyle deyimlerin toplanmasının farklı işler olduğuna, derlediği deyimlerin Türkçeden bir parçacık olduğuna, eserde deyimlerin dışında konuşmada sıkça kullanılan kalıp ifadelere de yer verdiğine, aslında eseri alfabetik düzenleme kararı almış olduğuna ancak kelimeler arasındaki bağlantının buna imkan tanımadığına, bu eserin Türkçenin daha iyi anlaşılmasına yardımcı olacağına değinir ve Viguer’nin sözünü aktarır:

“À considérer le tissu methodique et profondément combine du turk usuel, on serait tenté de croire qu'il est le résultat des conventions raisonées d'une société de savans.”

“Türklerin her zamanki metodik ve derinden birleştirilen dokusunu ele almak için, bunun bir savan toplumunun gerekçeli sözleşmelerinin bir sonucu olduğuna inanmak cazip olacaktır.”

Sayfa sonunda da Breslaw, 8 Ekim 1843 tarihi yer almaktadır.

Idiotismes de la Langue Turque başlı̆̆ıyla sunulan deyimler, Romen rakamlı sayfaların ardından Arap rakamlariyla 7. sayfadan devam etmiştir.

Fautes D’impression başlı̆̆ıyla baskı hataları 38. sayfada verilmiştir.

Eserde yer alan konular başka deyimlerde de geçmişse yanına hangi madde başı altında bulunduğu yazılmıştır. Böylelikle bir deyim iki konuyla ilgili ise o deyimi tasnif etmek kolaylaşmıştır.

\subsection{Eserde yer alan deyimler}

Deyimlerin konu düzeni aşağıdaki gibidir:

1. Ínsan organları (398 adet): baş (77 madde başı), ḳıl, șaç, tüy (6 madde başı), göz (53 madde başı), yüz (53 madde başı), burun ( 5 madde başı), ag̀ız (29 madde başı), dil (32 madde başı), ḳulaḳ (15 madde başı), ḳol (7 madde başı), el (57 madde başı), parmak (11 madde başı), țırnaḳ (4 madde başı), ayak (20 madde başı), boġaz (7 madde başı), ciger (12 madde başı), yürek (4 madde başı), ḳan (6 madde başı) 


\section{2. dostluk (23 madde başı)}

3. hayvanlar (50 adet): țavşan, tāzı (4 madde başı), ceyrān (3 madde başı), ḳoyun, ḳuzu, ḳoç (5 madde başı), köstebek (1 madde başı), ḳuş (15 madde başı), balık (9 madde başı), böcek (1 madde başı), sivrisiñek, siñek (1 madde başı), tepme (1 madde başı), boynuz (3 madde başı), ḳuyruḳ (2 madde başı), yumurța (1 madde başı), bal (4 madde başı)

\section{4. bitkiler (30 adet):}

arpa (3 madde başı), șog̉an, șarımsaḳ (2 madde başı), ıșırg̉an (2 madde başı), ḳamış (1 madde başı), kabak (2 madde başı), çiçek (2 madde başı), gül (1 madde başı), ag̉aç (5 madde başı), zeytūn (2 madde başı), bādem (2 madde başı), findık (1 madde başı), çınār (1 madde başı), dal, budaḳ (3 madde başı), çekirdek (1 madde başı), ḳılçıł (1 madde başı), șaman (1 madde başı)

\section{5. cansiz varlıklar (9o adet):}

țaş (12 madde başı), şap (2 madde başı), çamur (2 madde başı), ḳum (1 madde başı), toprak, yer (10 madde başı), kara (3 madde başı), țalğa, kenār, kıyı, deñiz (9 madde başı), batak, aḳıntı, țamla, șu (10 madde başı), havā, zamān (4 madde başı), kül, tütün, āteş (20 madde başı), ḥarāret, șogiuḳluk, dumān, yaġmur, ḳar (9 madde başı), ḳıble, yel (8 madde başı)

6. gök (27 adet): güneş, mehtāb, ay, yıldız, gölge, aydınlıḳ, ḳuyruḳlu yıldız (22 madde başı), gök (5 madde başı)

\section{1. İnsan organları (7-24. s.)}

baş (77 madde başı)

\begin{tabular}{|c|c|}
\hline baş (7.s.) & başa çılımaḳ (8. s.) \\
\hline yıl başı (7. s.) & başdan çılkarmaḳ (8. s.) \\
\hline ay başı (7. s.) & başdan çılkmaḳ (8. s.) \\
\hline aķçe başı (7. s.) & baş başa vérmek (8. s.) \\
\hline baş aġa (7. s.) & biriniñ başınıñ altından olmaḳ (8. s.) \\
\hline ḳavās başı (7. s.) & biriniñ başınıñ etini yémek (8. s.) \\
\hline başı eski (7. s.) & ‘aḳlım başımda degil (8. s.) \\
\hline baş tebdīl (7. s.) & balıḳ başdan ḳoḳar (9. s.) \\
\hline baş çavuş (7. s.) & ḳuş başı ḳar yaġar (9. s.) > ḳar, ḳuş \\
\hline çavuş başı (7. s.) & baş țaşa doḳunmaḳ (9. s.) > țaş \\
\hline şāhīnci başı (7. s.) > şāhīn & baş çatlamaḳ (9. s.) \\
\hline ḳuşcıbaşı (7. s.) > ḳuş & baş beyin gitmek (9. s.) \\
\hline baş ḳadın (7.s.) & başı țaşa gelmek (9. s.) > țaş \\
\hline başbug (7. s.) & baş yémek (9. s.) \\
\hline başı bozuk (7. s.) & baş ḳaşımaġa vaḳit olmamaḳ (9. s.) \\
\hline başı boş (7. s.) & baş dolanmaḳ (9. s.) \\
\hline başlık (8. s.) & bu baş neler çekmiş (9. s.) \\
\hline başdan ḳara olmaḳ (8. s.) & baş neler görmüş (9. s.) \\
\hline başdan baş (8. s.) & başıñ șağ olsuna varmaḳ (9. s.) \\
\hline başdan başa (8. s.) & baş göge degmek (9. s.) > gök \\
\hline baş aşağ 1 (8. s.) & başa ḳar yaġmaḳ (9. s.) > ḳar \\
\hline baş üzre (8. s.) & başdan yel esmek (9. s.) > yel \\
\hline baş üstine (8. s.) & başa āteş yaḳmaḳ (9. s.) > āteş \\
\hline dik başlı (8. s.) & biriniñ başına āteş yaġar (9. s.) > āteş \\
\hline baş étmek (8. s.) & biriniñ başına țaş düşer (9. s.) > țaş \\
\hline
\end{tabular}


Idioms book of Turkish: Spécimen des Idiotismes de la Languae Turque - Recueillis, classés par ordre de matières et expliqués / Y. Yilmaz; C. Aksoy (pp. 65-78)

\begin{tabular}{|c|c|}
\hline 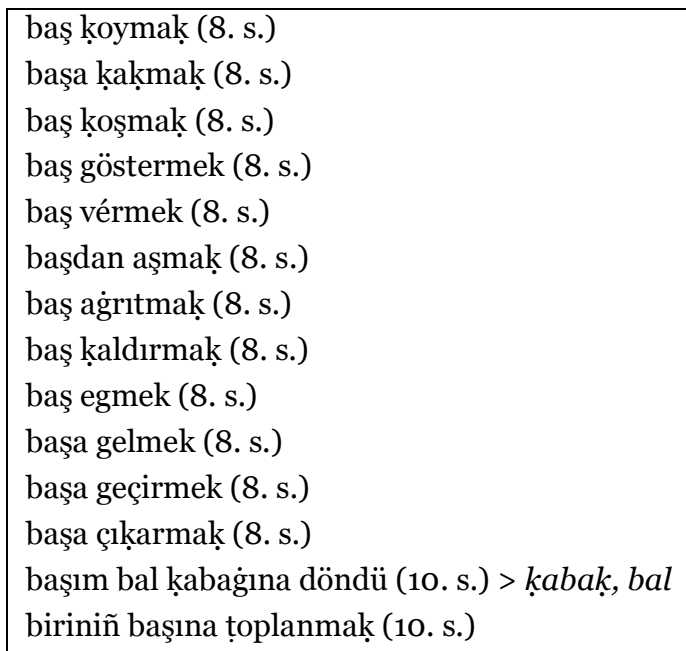 & $\begin{array}{l}\text { ţopraḳ başına (9. s.) > toprak } \\
\text { baş țaşdan țaşa urmak (9. s.) > țaş } \\
\text { el başa vurmak (9. s.) > el } \\
\text { iki elini başına urmaḳ (9. s.) > el } \\
\text { başınıñ çıḳdığ yere git (9. s.) > yer } \\
\text { başa baş almak (9. s.) } \\
\text { başa baş vérmek (10. s.) } \\
\text { başa șarmaḳ (10. s.) } \\
\text { başa su degmek (10. s.) } \\
\text { biriniñ başına (başıma, başına) ot bitmez (10. s.) } \\
\text { başım șaġdır (10. s.) } \\
\text { başı açık (10. s.) } \\
\text { başı țaşra (10. s.) }\end{array}$ \\
\hline
\end{tabular}

\section{ḳıl, șaç, tüy (6 madde başı)}

\begin{tabular}{|l|l|}
\hline ḳılı ḳırk yarmaḳ (10. s.) & saçı bıçık (10. s.) \\
sade yağından kıl çekmek (10. s.) & tüy dikmek (10. s.) \\
saçı (10. s.) & ağza tüy bitmek (10. s.) > ag̀gı \\
\hline
\end{tabular}

\section{göz (53 madde başı)}

\begin{tabular}{|c|c|}
\hline bir iki üç dört göz pencere (10. s.) & gözden geçirmek (12. s.) \\
\hline göz (11. s.) & göz ḳoymaḳ (12. s.) \\
\hline göz yaşı (11. s.) & göz degmek (12. s.) \\
\hline havānıñ gözü yaşlı (11. s.) > havā & göz urmaḳ (12. s.) \\
\hline terazi gözü (11. s.) & göz ḳırpmaḳ (12. s.) \\
\hline çekmece gözü (11. s.) & gözden tütmek (12. s.) \\
\hline gözcü (11. s.) & göze girmek (12. s.) \\
\hline gözü pek (11. s.) & gözden çıḳmaḳ (12. s.) \\
\hline gözü açıḳ (11. s.) & gözden düşmek (12. s.) \\
\hline açık göz (11. s.) & göze almaḳ (12. s.) \\
\hline açık gözlü (11. s.) & gözden almaḳ (12. s.) \\
\hline göz açmaḳ (11. s.) & göz almaḳ (12. s.) \\
\hline gözü ḳapalı (11. s.) & göze gelmek (12. s.) \\
\hline gözü fenā (11. s.) & göz vérmek (12. s.) \\
\hline göz bayıcı (11. s.) & göz ile yémek (12. s.) \\
\hline gözündeki (11. s.) & göz ḳızarmaḳ (12. s.) \\
\hline göz țaşı (11. s.) > țaş & göz ḳulaḳ olmak (12. s.) \\
\hline göz göre (11. s.) & (gözüm, gözüñ) gözü șogiur (12. s.) \\
\hline gözlük (11. s.) & gözü keser (12. s.) \\
\hline ḳuş gözü (11. s.) & gözü ıșırır (12. s.) \\
\hline ceyrān gözlü (12. s.) > ceyrān & göz kestirmek (12. s.) \\
\hline şāhīn gözlü (12. s.) > şāhin & göz aydına gitmek (13. s.) > aydınlık \\
\hline gözü budaḳdan șaḳınmaz (12. s.) > budak & göze kül ufurmaḳ (13. s.) > kül \\
\hline gözetmek (12. s.) & göz beletmek (13. s.) \\
\hline gözlemek (12. s.) & göz göz olmak (13. s.) \\
\hline göz etmek (12. s.) & göz șoḳmaḳ (13. s.) \\
\hline göz geçirmek (12. s.) & \\
\hline
\end{tabular}

\section{yüz (53 madde başı)}

\begin{tabular}{|c|c|}
\hline yüz (13. s.) & yüz görümlügü (14. s.) \\
\hline $\begin{array}{r}\text { Adres } \\
\text { Kırklareli Üniversitesi, Fen Edebiyat Fakültesi, Türk Dili ve Edebiyatı } \\
\text { Bölümü, Kayalı Kampüsü-Kırklareli/TÜRKİYE } \\
\text { e-posta: editor@rumelide.com }\end{array}$ & $\begin{array}{l}\text { Adress } \\
\text { Kırklareli University, Faculty of Arts and Sciences, Department of } \\
\text { Turkish Language and Literature, Kayalı Campus-Kırklareli/TURKEY } \\
\text { e-mail: editor@rumelide.com }\end{array}$ \\
\hline
\end{tabular}




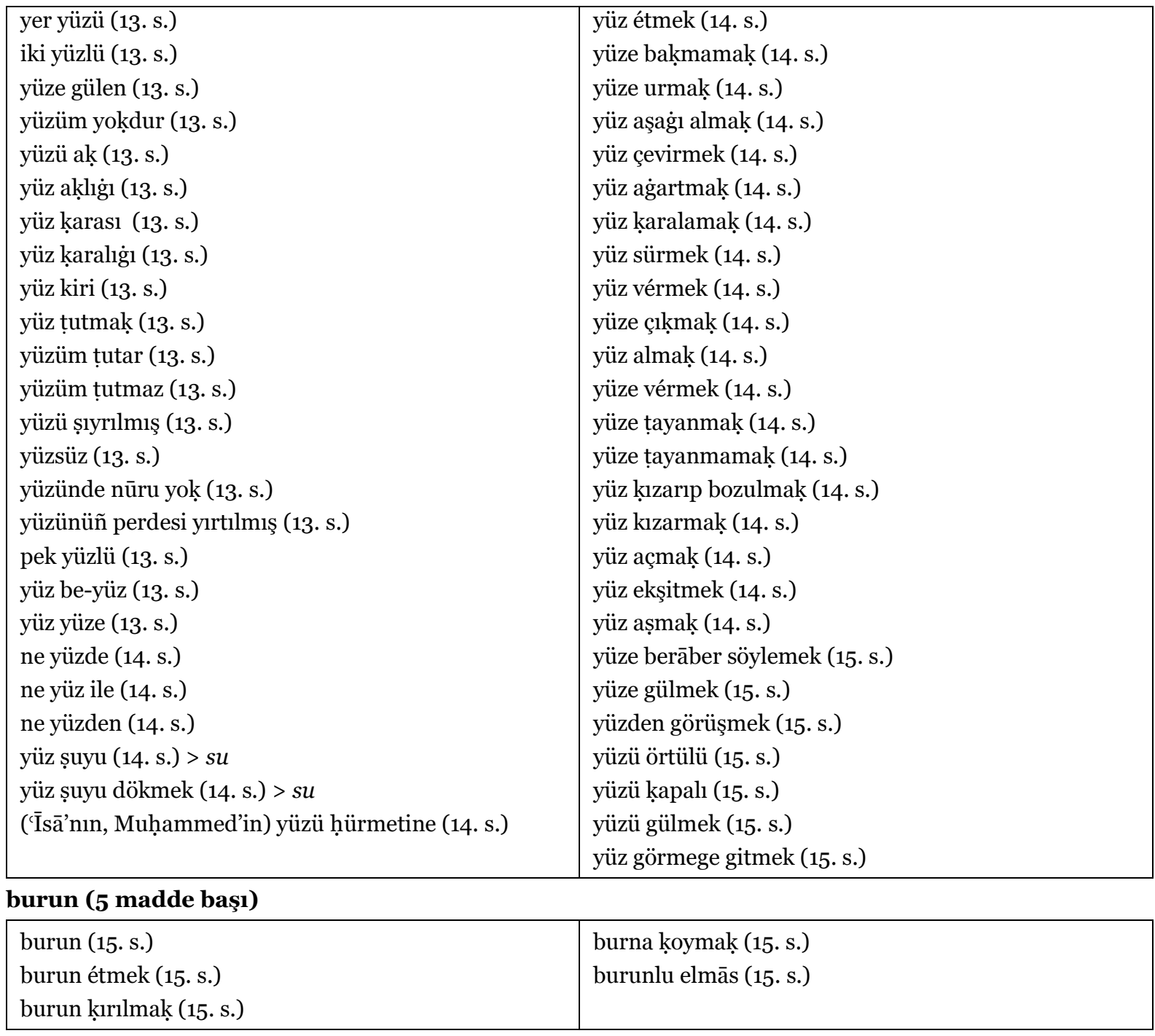

\section{ag̀ız (29 madde başı)}

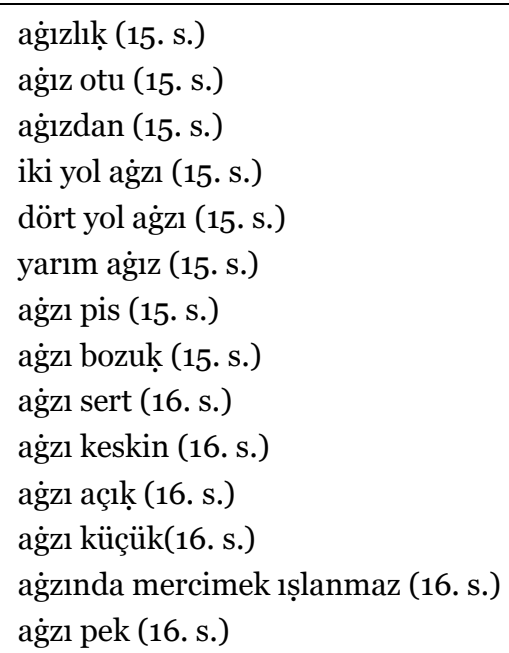

bu benim aġzımın kaşı̀̆ı degil (16. s.)aġza gelmek (16. s.) aġzı varmaḳ (16. s.) ag̉zı yaḳmaḳ (16. s.)aġız yanmaḳ (16. s.) ağız étmek (16. s.) ag̉za ḳoymaḳ (16. s.) aġza götürmek (16. s.) ağızlamak (16. s.) ag̉za dil ḳoymak (16. s) > dil aǵza tüy bitmek (16. s.) > tüy ag̉za ḳayık ḳanışmamak (16. s) aġı aġıa gelmek (16. s.) șaǵ ḳol aǵzı (16. s.) > kol ṣol ḳol ag̉zı (16. s.) > kol

\section{dil (32 madde başı)}

dil (16. s.)

çañ dili (16. s.) küçük dil (17. s.)

dil yarası (17. s.) 
Idioms book of Turkish: Spécimen des Idiotismes de la Languae Turque - Recueillis, classés par ordre de matières et expliqués / Y. Yilmaz; C. Aksoy (pp. 65-78)

\begin{tabular}{|c|c|}
\hline terāzī dili (16. s.) & dilleşmek (17. s.) \\
\hline dil otu (16. s.) & dile vérmek (17. s.) \\
\hline dil otu yemiş (17. s.) & dil uzatmaḳ (17. s.) \\
\hline dilbāz (17. s.) & dil ile șovutmaḳ (17. s.) \\
\hline dil altı (17. s.) & dil bilmez (17. s.) \\
\hline dili bozuk (17. s.) & dil țutmaḳ (17. s.) \\
\hline dili pertevsiz (17. s.) & dil almak (17. s.) \\
\hline dili uzun (17. s.) & dilini țutmaḳ (17. s.) \\
\hline dili fenā (17. s.) & dil çekmek (17. s.) \\
\hline dili pis (17. s.) & dil dökmek (17. s.) \\
\hline dil ile ta bīir olunmaz (17. s.) & dile destān olmaḳ (17. s.) \\
\hline dile gelmez (17. s.) & dilden dile yayılmak (17. s.) \\
\hline dili țutuḳ (17. s.) & dil pāslıdır (17. s.) \\
\hline dili aġır (17. s.) & 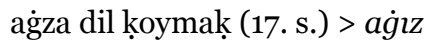 \\
\hline
\end{tabular}

\section{ḳulaḳ (15 madde başı)}

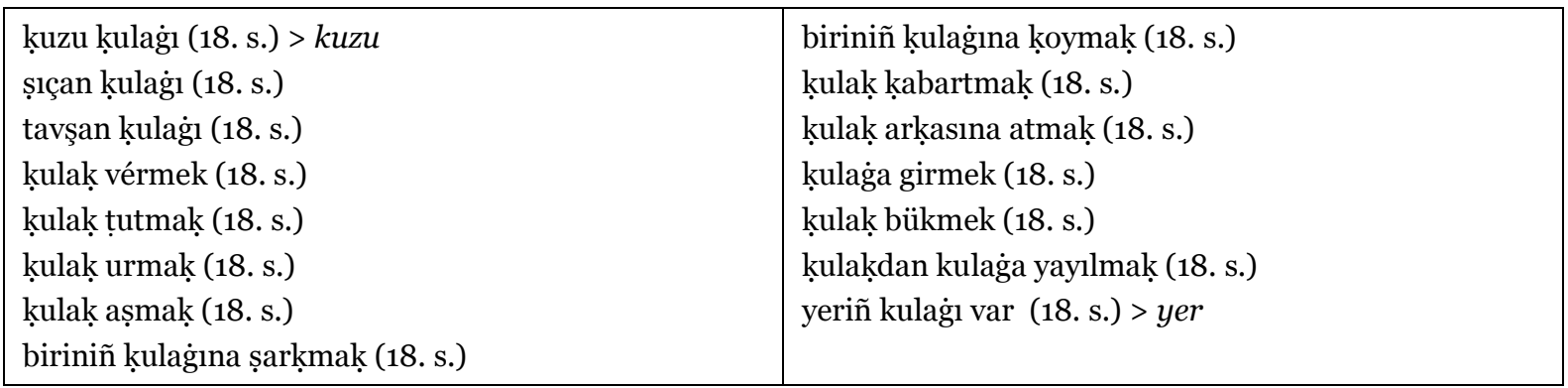

\section{ḳol (7 madde başı)}

ḳol gözetmek : ḳollamaḳ (18. s.)

kol kola vérmek (18. s.)

kolcu (18. s.)

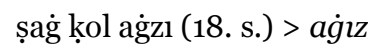

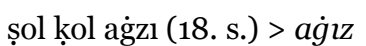

kol demiri (18. s.)

ḳol degnegi (18. s.)

\section{el (57 madde başı)}

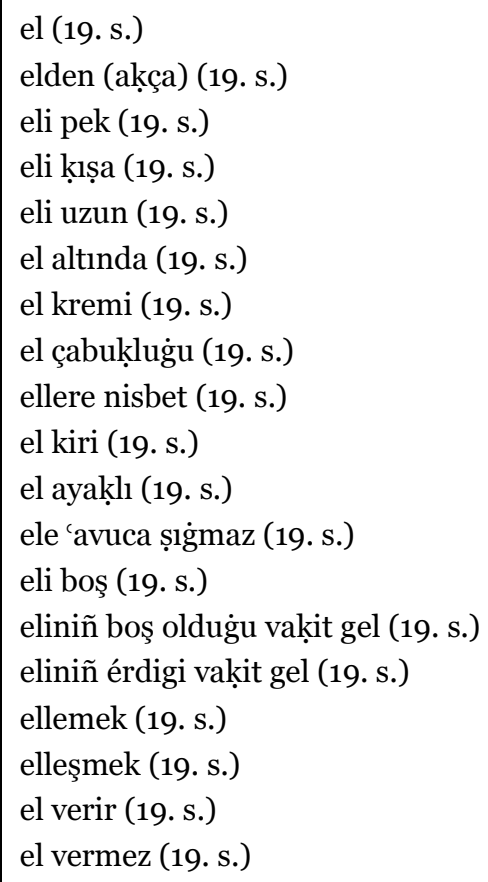

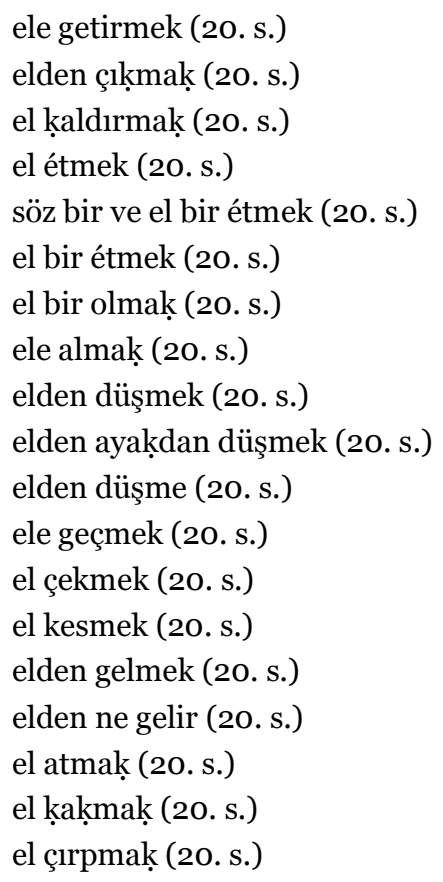




\begin{tabular}{|c|c|}
\hline $\begin{array}{l}\text { el vérmek (19. s.) } \\
\text { el țutmaḳ (19. s.) } \\
\text { ele vérmek (19. s.) } \\
\text { el ele vérmek (19. s.) } \\
\text { el ḳoymaḳ (20. s.) } \\
\text { el urmaḳ (20. s.) } \\
\text { el başa urmak (20. s.) } \\
\text { iki elini başına urmaḳ (20. s.) } \\
\text { el bag̀lamaḳ (20. s.) } \\
\text { el kavușdurmak (20. s.) }\end{array}$ & $\begin{array}{l}\text { yaḳayı ele vérmek (20. s.) } \\
\text { elimde degil (20. s.) } \\
\text { elimdedir (20. s.) } \\
\text { eldedir (21. s.) } \\
\text { el yatmaḳ (21. s.) } \\
\text { el eline yatmaḳ (21. s.) } \\
\text { el elinde ḳalmaḳ (21. s.) } \\
\text { el ḳapısında olmaḳ (21. s.) } \\
\text { el el ile yılan țutmaḳ (21. s.) }\end{array}$ \\
\hline
\end{tabular}

\section{parmak (11 madde başı)}

\begin{tabular}{|l|l|}
\hline tekerler parmaḳları (21. s.) & parmaḳ koymaḳ (21. s.) \\
parmaḳ ḥesābı (21. s.) & parmaḳ ısırmạ̣ (21. s.) \\
parmağla gösterirler ki (21. s.) & parmaḳ ḳaralamaḳ (21. s.) \\
parmaḳlamaḳ (21. s.) & parmaḳ üstünde oynatmaḳ (21. s.) \\
içinde parmag்ı olmaḳ (21. s.) & pür parmaḳ bal olmaḳ (21. s.) > bal \\
parmağı bir olmaḳ (21. s.) & \\
\hline
\end{tabular}

\section{țirnak (4 madde başı)}

țirnaḳlamaḳ (21. s.)

ḳaşınacak tırnaḳ olmamaḳ (21. s.)

et țirnaḳdan ayrılmaz (21. s.)

țırnaḳ alışdırmaḳ (21. s.)

\section{ayak (20 madde başı)}

ayaḳkabı (22. s.)
ayaḳ yolu (22. s.)
ayaḳ altı yer (22. s.)
ayaḳdaş (22. s.)
kırk ayaḳ (22. s.)
nerdüban ayag்ı (22. s.)
ayaḳ üstü (22. s.)
ayaḳ ayaġı (22. s.)
ayaġı tozuyla (22. s.)
ayaḳ basmak (22. s.)

ayaḳda durmaḳ (22. s.)

ayağa durmak (22. s.)ayağı şaşırmaḳ (22. s.)

eli ayaḳlı (22. s.) > el

elden ayaḳdan düşmek (22. s.) $>$ el

ayaġa ḳalkmaḳ (22. s.)

ayaġa ḳaldırmak (22. s.)

ayaḳ üzere ḳalmak (22. s.)

ayaḳlanmak (22. s.)

ayaḳlamak (22. s.)

\section{bogaz ( 7 madde başı)}

\begin{tabular}{|l|l|}
\hline boġaz (22. s.) & pis boġaz (23. s.) \\
boş boġaz (23. s.) & boġazsız (23. s.) \\
boġazlı (23. s.) & boġaz boġaza olmaḳ (23. s.) \\
boġaz aver (23. s.) & \\
\hline
\end{tabular}

\section{ciger (12 madde başı)}

\begin{tabular}{|c|c|}
\hline $\begin{array}{l}\text { aḳciger (23. s.) } \\
\text { ķaraciger (23. s.) } \\
\text { cigerim (23. s.) } \\
\text { ciger köşem (23. s.) } \\
\text { ciger pārem (23. s.) } \\
\text { cigerden (23. s.) }\end{array}$ & $\begin{array}{l}\text { cigerden sevmek (23. s.) } \\
\text { cigerli (23. s.) } \\
\text { ciger yaḳmaḳ (23. s.) } \\
\text { ciger yanmak (23. s.) } \\
\text { ciger delmek (23. s.) } \\
\text { cigere degmek (23. s.) }\end{array}$ \\
\hline \multicolumn{2}{|l|}{ yürek (4 madde başı) } \\
\hline $\begin{array}{l}\text { yürek uyanmaḳ (23. s.) } \\
\text { yürek vérmek (23. s.) }\end{array}$ & $\begin{array}{l}\text { yürek almaḳ (23. s.) } \\
\text { yürek șaḳlamak (23. s.) }\end{array}$ \\
\hline
\end{tabular}


Idioms book of Turkish: Spécimen des Idiotismes de la Languae Turque - Recueillis, classés par ordre de matières et expliqués / Y. Yllmaz; C. Aksoy (pp. 65-78)

\section{ḳan (6 madde başı)}

ḳan ḳaynamaḳ (24. s.)
ḳan dökmek (24. s.)
deliḳanlı (24. s.)

ḳan almak (24. s.)

kan țaşı (24. s.) > taş

kan étmek (24. s.)

\section{2. dostluk (23 madde başı) (24-25. s.)}

\begin{tabular}{|l}
\hline cānım (24. s.) \\
cānlı (24. s.) \\
cānsız (24. s.) \\
cān u göñülden (24. s.) \\
cān evi (24. s.) \\
cānı pek (24. s.) \\
cānı az (24. s.) \\
cānı tez (24. s.) \\
cānı haḳkı̣ (24. s.) \\
bin cān ile (24. s.) \\
cān atmaḳ (24. s.) \\
cān vérmek (24. s.)
\end{tabular}

cān acitmak (24. s.)

cān çılıarmaḳ (24. s.)

cān çıkmaḳ (24. s.)

cān tāzelemek (24. s.)

cān çekişmek (25. s.)

cāndan sevmek (25. s.)

cāndan geçmek (25. s.)

cān ṣıḷılmaḳ (25. s.)

cānlanmaḳ (25. s.)

cān yaḳmaḳ (25. s.)

cān yanmaḳ (25. s.)

\section{3. hayvanlar (25-29. s.)}

țavşan, tāzı (4 madde başı)

\begin{tabular}{|l|l|}
\hline $\begin{array}{l}\text { țavşana ḳaç tāzıya țut söylemek (25. s.) } \\
\text { țavşan ḳulağı (25. s.) }\end{array}$ & $\begin{array}{l}\text { țavşancıl ḳuşu (25. s.) } \\
\text { țavşan uyḳusu (25. s.) }\end{array}$ \\
\hline
\end{tabular}

\section{ceyrān (3 madde başı)}

\begin{tabular}{|l|l|}
\hline $\begin{array}{l}\text { ceyrān gözlü (25. s.) > göz } \\
\text { ceyrān baḳışlı (25. s.) }\end{array}$ & ceyrān gibi (25. s.) \\
\hline
\end{tabular}

\section{ḳoyun, ḳuzu, ḳoç (5 madde başı)}

\begin{tabular}{|l|l|}
\hline ḳoç (25. s.) & ḳuzu kulaġı (26. s.) \\
ḳoçum (26. s.) & ḳoyun gözü (26. s.) \\
ḳuzum (26. s.) & \\
\hline
\end{tabular}

\section{köstebek (1 madde başı)}

köstebek (26. s.)

\section{ḳuş (15 madde başı)}

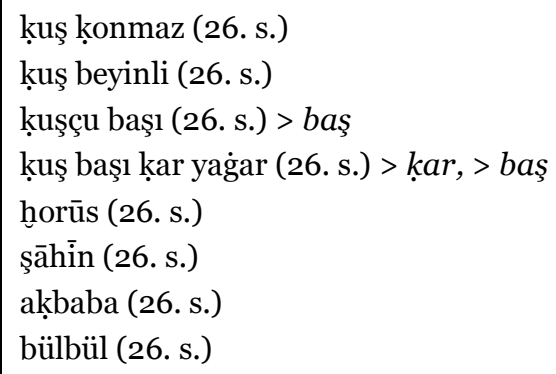

țūtịi (26. s.)

aḳbabaya dönmüş (26. s.)

şāhīn gözlü (27. s.) > göz

şāhīnci başı (27. s.) > baş

horūs aḳıllı (27. s.)

horūs ibigi (27. s.)

țūṭi dilli (27. s.)

\section{balık (9 madde başı)}

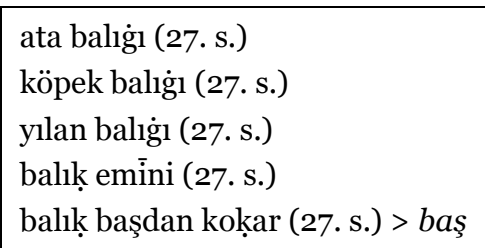

balık dikeni (27. s.)

balık ḳanadı (27. s.)

balık kemigi (27. s.)

balık pulu (27. s.) 
böcek (1 madde başı)

\begin{tabular}{|c|c|}
\hline böcek (28. s.) & \\
\hline sivrisiñek, siñe & \\
\hline siñeklik (28. s.) & siñek pekmezciyi țanır (28. s.) \\
\hline
\end{tabular}

\section{tepme (1 madde başı)}

tepme (28. s.)

\section{boynuz ( 3 madde başı)}

\begin{tabular}{|l|l|}
\hline $\begin{array}{l}\text { boynuzlu (28. s.) } \\
\text { boynuz çekmek (28. s.) }\end{array}$ & keçi boynuzu (28. s.) \\
\hline
\end{tabular}

ḳuyruk ( 2 madde başı)

\begin{tabular}{l|l|}
\hline ḳuyruḳlu yıldız (28. s.) & ḳuyruḳ acısı var (28. s.) \\
yumurța (1 madde başı) \\
\hline yumurțlamaḳ (28. s.)
\end{tabular}

\section{bal ( 4 madde başı)}

\begin{tabular}{|l|l}
\hline bir parmaḳ bal olmaḳ (29. s.) > parmaḳ & bal bal démekle ağız țatlı olmaz (29. s.)
\end{tabular}

başım bal ḳabag̉ına döndü (29. s.) > baş, > ḳabaḳ $\quad$ bal ḳurt (29. s.)

\section{4. bitkiler (29-31. s.)}

arpa (3 madde başı)

arpa șuyu (29. s.)
arpalıḳ (29. s.)

\section{șoġan, șarımsaḳ ( 2 madde başı)}

anañ șoġañ babañ șarımsaḳ sen kime çıḷdıñ [çekdiñ] gülbeşeker3 (29. s.)

\section{ıșırgàn (2 madde başı)}

\begin{tabular}{l|l|}
\hline ıṣırgaan ile göt silmek (29. s.) & ıṣırgaan țahāret étmek (29. s.) \\
ḳamış (1 madde başı) & \\
\hline ḳamış (30. s.)
\end{tabular}

\section{kabaḳ ( 2 madde başı)}

\begin{tabular}{|c|c|}
\hline kabaḳ taḳım (30. s.) & başım bal ḳabaġına döndü (30. s.) > bal, > baş \\
\hline \multicolumn{2}{|l|}{ çiçek ( 2 madde başı) } \\
\hline ne çiçekdir (30. s.) & çoḳ çiçekdir (30. s.) \\
\hline \multicolumn{2}{|l|}{ gül (1 madde başı) } \\
\hline \multicolumn{2}{|l|}{ gül panayırı (30. s.) } \\
\hline \multicolumn{2}{|l|}{ ag̉aç (5 madde başı) } \\
\hline $\begin{array}{l}\text { aġaç ḳavunu (30. s.) } \\
\text { aġaç ḳavı (30. s.) } \\
\text { aġaç (30. s.) }\end{array}$ & $\begin{array}{l}\text { ag̉aç (30. s.) } \\
\text { aǵaç (30. s.) }\end{array}$ \\
\hline \multicolumn{2}{|l|}{ zeytūn ( 2 madde başı) } \\
\hline aġzına bir zeytūn vérip götüne bir țulum țutmaz (30. s.) & $\begin{array}{l}\text { ay aydınlıġından zeytūn silkmek (31. s.) > aydınlık, > } \\
\text { ay }\end{array}$ \\
\hline
\end{tabular}


Idioms book of Turkish: Spécimen des Idiotismes de la Languae Turque - Recueillis, classés par ordre de matières et expliqués / Y. Yılmaz; C. Aksoy (pp. 65-78)

bādem (2 madde başı)

\begin{tabular}{|c|c|}
\hline bādem (31. s.) & bādemci (31. s.) \\
\hline \multicolumn{2}{|c|}{ findık (1 madde başı) } \\
\hline \multicolumn{2}{|l|}{ findıkẹçı (31. s.) } \\
\hline çınār (1 madde & \\
\hline
\end{tabular}

\section{dal, budak (3 madde başı)}

\begin{tabular}{|l|l|}
\hline $\begin{array}{l}\text { göz budaḳdan șaḳınmaz (31. s.) > göz } \\
\text { dal yazılmaḳ (31. s.) }\end{array}$ & dal ḳavaḳ (31. s.) \\
\hline
\end{tabular}

\section{çekirdek (1 madde başı)}

çekirdekden yetme (31. s.)

\section{kulç̣ı (1 madde başı)}

\begin{tabular}{|l|l|}
\hline balık ḳ̣lçığı (31. s.) & \\
șaman (1 madde başı) & \\
\hline șaman uğrusu (31. s.) & \\
\hline
\end{tabular}

\section{5. cansiz varlıklar (32-36. s.)}

țaş (12 madde başı)

\begin{tabular}{|c|c|}
\hline $\begin{array}{l}\text { göz țaşı (32. s.) > göz } \\
\text { ḳan țaşı (32. s.) > ḳan } \\
\text { țaş atmaḳ (32. s.) } \\
\text { țaş urmaḳ (32. s.) } \\
\text { meyveli agàaca herkes țaş atmaz (32. s.) } \\
\text { bin ceviz görmedikçe bir țaş atmaz (32. s.) }\end{array}$ & $\begin{array}{l}\text { başına țaşdan țaşa urmak (32. s.) > baş } \\
\text { țaş kesilmek (32. s.) } \\
\text { țaşlamaḳ (32. s.) } \\
\text { başı țaşa dokunmak (32. s.) > baş } \\
\text { başı țaşa gelmek (32. s.) > baş } \\
\text { baş țaşana țaş düşer (32. s.) > baş }\end{array}$ \\
\hline \multicolumn{2}{|l|}{ şap (2 madde başı) } \\
\hline şapa oturmaḳ (32. s.) & şapda bir şekerde bir söylemek \\
\hline \multicolumn{2}{|l|}{ çamur ( 2 madde başı) } \\
\hline çamura düşmek (32. s.) & üstüne çamur sıçramaḳ (32. s.) \\
\hline \multicolumn{2}{|l|}{ ḳum (1 madde başı) } \\
\hline \multicolumn{2}{|l|}{ ḳuma oturmak (33. s.) } \\
\hline \multicolumn{2}{|l|}{ toprak, yer (10 madde başı) } \\
\hline $\begin{array}{l}\text { bu yerde }>\text { burada }(33 . \text { s.) } \\
\text { ne yerde }>\text { nerede }(33 . \text { s.) } \\
\text { yerli }(33 . \text { s.) } \\
\text { yer yüzü }(33 . \text { s.) > yüz } \\
\text { başıñ çı̣̂dığ yere git }(33 . \text { s. })>\text { baş }\end{array}$ & $\begin{array}{l}\text { yere geçmek (33. s.) } \\
\text { yere düşmek (33. s.) } \\
\text { yere urmaḳ (33. s.) } \\
\text { yerden yere çarpmak (33. s.) } \\
\text { topraḳ başına (33. s.) > baş }\end{array}$ \\
\hline \multicolumn{2}{|l|}{ ḳara (3 madde başı) } \\
\hline $\begin{array}{l}\text { ḳaraya oturmak (33. s.) } \\
\text { ḳaraya düşmek (33. s.) }\end{array}$ & ḳaraya etmek (33. s.) \\
\hline \multicolumn{2}{|l|}{ țalġa, kenār, ḳıyı, deñiz (9 madde başı) } \\
\hline $\begin{array}{l}\text { deñiz aşırı (33. s.) } \\
\text { deñiz düşen yılana șarılır (33. s.) } \\
\text { lāḳ ile pilav pişer ise deñiz ḳadar yag benden (34. s.) }\end{array}$ & $\begin{array}{l}\text { ḳıyılar seçilmek (34. s.) } \\
\text { ḳıyılar seçilmek (34. s.) } \\
\text { ḳııı șuları ile bamınmaḳ (34. s.) }\end{array}$ \\
\hline
\end{tabular}


\begin{tabular}{|l|l|}
\hline kenār (34. s.) & ḳıllar bulmak (34. s.)
\end{tabular}

țalgalanmaḳ (34. s.)

\section{bataḳ, aḳıntı, țamla, șu (10 madde başı)}

\begin{tabular}{|l|l|}
\hline başa șu degmek (34. s.) > baş & aḳmaz ise de țamlar (34. s.) \\
țamla (34. s.) & aḳındıya kürek çekmek (34. s.) \\
țamla étmek (34. s.) & işi bataḳ olmaḳ (34. s.) \\
țamlaya țamlaya göl olur (34. s.) & banḳacı (34. s.) \\
țamlalı (34. s.) & banḳacıllı̣ (34. s.)
\end{tabular}

\section{havā, zamān (4 madde başı)}

havāda nem ḳapmaḳ (34. s.)

kendi havāsına girmek (34. s.)

havāda gezmek (34. s.)

havālanmak (34. s.)

\section{kül, tütün, āteş (20 madde başı)}

āteş gibi (35. s.)
āteşden gömlekdir (35. s.)
āteşkede (35. s.)
başa āteş yaḳmaḳ (35. s.) > baş
başa āteş yanmaḳ (35. s.) > baş
āteş vérmek (35. s.)
āteş étmek (35. s.)
āteş almak (35. s.)
āteş böcegi (35. s.)
biriniñ başina āteş yagaar (35. s.) > baş
āteşlenmek (35. s.)

\section{harāāet, șog̉uḳluk, dumān, yaġmur, ḳar (9 madde başı)}

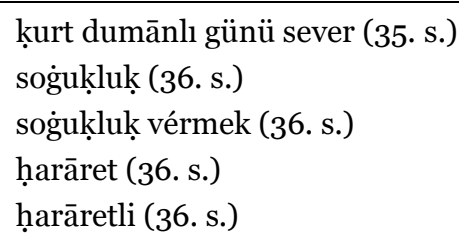

tütün içmek (35. s.)

tütün çekmek (35. s.)

küle oturmak (35. s.)

kül étmek (35. s.)

kül göze üfürmek (35. s.)

külhān (35. s.)

külhānī (35. s.)

külhāncı (35. s.)

seni hamāmcı éden beni de bir külhāncı éder (35. s.)

\section{ḳıble, yel (8 madde başı)}

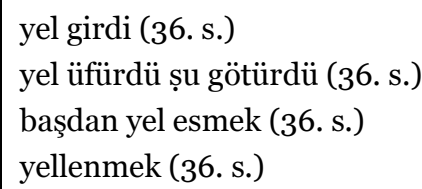

kuş başı kar yag̉ar (36. s.) > kuş, > baș başa ḳar yaġmak (36. s.) > baş yaġmurdan ḳaçıp doluya rast gelmek (36. s.) yaġmurlu günde țavuga su véren çoḳ olur (36. s.)

\section{6. gök (36-38. s.)}

güneş, mehtāb, ay, yıldız, gölge, aydınlık, ḳuyruḳlu yıldız (22 madde başı) ay çiçegi (36. s.)

ay başı (37. s.) > baş

ay gibi (37. s.)

ay çarpmıș (37. s.)

ay aydın hesāb belli (37. s.) > aydınlık

kible (36. s.)

ḳıble-nümā (36. s.)

kılblesiz (36. s.)

ḳıblegāh-ı 'ālem (36. s.)

ay aydınlığına zeytūn silkmek (37. s.) > zeytūn, > aydınlık

mehtāb (37. s.)

bir kimse ile mehtāb étmek (37. s.)

göz aydına gitmek (37. s.) > göz ay aydın heseāb belli (37. s.) > ay ay aydınlığına zeytūn silkmek (37. s.) > ay gölge (37. s.) yıldız (37. s.) yıldı gibi (37. s.) yıldız yüksekligi (37. s.) yıldız açıklığı (37. s.) 


\begin{tabular}{|l|l|}
\hline $\begin{array}{l}\text { ḳandili mehtāb étmek (37. s.) } \\
\text { güneşlik (37. s.) } \\
\text { güneş gibi (37. s.) }\end{array}$ & $\begin{array}{l}\text { ḳuyruḳlu yıldız țog்maḳ (37. s.) } \\
\text { bu dünyā bir ḳuyruḳlu yıldızdır ‘aşḳ olsun kesip yine } \\
\text { (37. s.) } \\
\text { ḳırḳ yılda bir ḳuyruḳlu yıldız țog̀ar (37. s.) }\end{array}$ \\
\hline
\end{tabular}

gök (5 madde başı)

baş göge degmek (37. s.)

gökden ne yağmış ki yer ḳabūl étmemiş (38. s.)

gök ḳubbe altında (38. s.) gök ḳandīl olmaḳ (38. s.)

gök gürüldemedikçe gāvur allah allāh démez (38. s.)

\section{Sonuç}

Deyimler, her dilin en işlenmiş söz varlığı unsurlarındandır. Edebiyatta zevkle ve sanatla kullanılan deyimler, dillerin sanatkâr yönünü göstermesi bakımından çok önemlidir. Kuruluşu sanatlı ve anlaması zahmetli olduğundan diğer söz varlı̆̆ı unsurlarına göre deyimlerin öğrenilmesi geç gerçekleşmektedir. Özellikle yabancıların Türkçe öğrenme sürecinde bu durum çok daha dikkat çekici olmaktadır.

$\mathrm{Bu}$ çalışmada yer alan ve deyim olarak sunulan söz varlı̆̆ının günümüz anlayışına göre bir kısmı atasözlerine, bir kısmı temel söz varlığına, bir kısmı terimlere, bir kısmı ilişki sözlere ve kalan kısmı da deyimlere girmektedir. Bu ayrımı yapmak için ayrıca bir çalışmaya ihtiyaç vardır.

Yabancıların Türkçe öğrenme süreci çok eskilere dayanmaktadır. Dil öğrenmenin gramer ve metinden ibaret olduğu anlayışının geçersizliği anlaşılmaya başlandıktan sonra, dilde yer alan söz varlığı unsurları daha dikkatli incelenmiş, irdelenmiş ve özellikle deyimlerin öğrenilmesinin zorluğu anlaşılınca bu konu üzerine çalışmalar yoğunlaşmıştır.

Yaklaşık 38 sayfadan ibaret olan ve Türkçenin sadece deyimlerini ele alan Spécimen des Idiotismes de la Languae Turque - Recueillis, classés par ordre de matières et expliqués (Türkçenin Örnekli Deyimleri- Toplu, Maddeleri sırah ve tasnifli, Açılamalı) adlı eser, deyim sözlüğü olma özelliği taşıyan, 1843 tarihli, tematik olması bakımından değerli bir eserdir. Eserde deyim adı altında yer alan madde başlarının hangilerinin deyimleşmeyi tamamladığı ya da tam deyim-1. dereceden deyim olduğu, hangilerinin yarı deyim-2. dereceden deyim olduğu, hangilerinin 3. dereceden deyim olduğu ya da hangilerinin deyim olmayan yapılardan sayılması gerektiği özellikle incelenmelidir.

\section{Kaynakça}

Aksan, D. (1995). Her Yönüyle Dil Ana Çizgileriyle Dilbilim (8 b.). Ankara: TDK.

Aksoy, Ö. A. (1994). Atasözleri ve Deyimler Sözlüğü-Atasözleri Sözlüğü (9 b., Cilt 2). İstanbul: İnkllâp. Ayverdi, İ. (2011). Misalli Büyük Türkçe Sözlük (2 b.). İstanbul: Kubbealtı-Milliyet.

Demir, C. (2008, Mayıs). Türkçede Deyimlerin Dizimsel Özellikleri. Türk Dili Dil ve Edebiyat Dergisi, 45(677), 428-444.

Eminoğlu, E. (2010). Türk Dilinin Sözlükleri ve Sözlükçülük Kaynakçası. Sivas: Asitan.

Korkmaz, Z. (1992). Gramer Terimleri Sözlüğü. Ankara: TDK.

Roehrig, F. L. (1843). Spécimen des Idiotismes de la Languae Turque - Recueillis, classés par ordre de matières et expliqués. Breslav : Ferdinand Hirt.

Subaşı Uzun, L. (1991). Deyimleşme ve Türkçede Deyimleşme Dereceleri. Dilbilim Araştırmaları, 2939.

Topaloğlu, A. (1989). Dil Bilgisi Terimleri Sözlüğü. İstanbul : Ötüken. 